\title{
WHY We CAN'T StOP Fighting ABOUT CHAUCER's MAN OF LAW
}

\author{
Bonnie J. Erwin \\ Custance's pale face summarizes what I have always felt as the \\ fundamental instability of the tale: the hollowness of the extreme pathos \\ and rhetorical affect of heroine and her narrator. ${ }^{1}$
}

As Chaucer's Canterbury pilgrims compete in their Host's tale-telling challenge, they bicker and mock one another, form both alliances and rivalries, and critique one another's religiosity, gender performance, and social class pretensions. These characters are an emotional lot, not least among them the Man of Law, a narrator who tells a heart-wrenching tale that moves even the teller; he pleads ardently for his audience to feel his heroine's travails, while also exhorting them to condemn his antagonists. What's more, we Chaucerians who study the tale of Custance sometimes resemble the lawyer-narrator in our tendency to be affectively transported by our subject matter. Inspiring more intense responses than many of the other Canterbury selections, the Man of Law's Tale makes critics take sides. In particular, we argue about whether the narrator bears a sincere or ironic relationship to Chaucer's own views. ${ }^{2}$ We struggle to define the

For their generous and fruitful comments - entirely eschewing the contentious modes of scholarly discourse I discuss above-I am grateful to colleagues at two conferences who heard nascent portions of my ideas on Custance and affect. I have benefitted from invaluable feedback offered by panel audiences at the Medieval Association of the Midwest 2013 conference (Terre Haute, Indiana) and the Ohio Medieval Colloquium Spring 2014 symposium (Columbus, Ohio). I appreciate as well the helpful revision suggestions I received from anonymous readers at Enarratio.

${ }^{1}$ Carolyn Dinshaw, "Pale Faces: Race, Religion, and Affect in Chaucer's Texts and Their Readers," Studies in the Age of Chaucer 23 (2001), 24.

${ }^{2}$ A.C. Spearing offers one of the more strident arguments against reading the Man of Law as an unreliable narrator. He goes so far as to say that "to read the Man of Law's Tale as spoken in the voice of a fictional narrator is usually to avoid reading it all" (Textual Subjectivity, 136). Among those who read the Man of Law as a flawed narrator, Laurel Hendrix contends that economics are at the heart of the problem and suggests that "Chaucer's lawyer collapses the distinction between spiritual, verbal, and monetary exchange, attempting to reduce Custance and Christ into signs which are freely traded and manipulated for profit, and the act of 'enditing' itself into a form of merchandising" ("Pennannce Profitable: The Currency of Custance in Chaucer's Man of Law's Tale," Exemplaria 6, no. 1 [1994], 141). Taking a middle road on the narrator question is Kathryn Lynch, who suggests that despite some of the problematic views on money attributed to the Man of Law in his General Prologue portrait, Chaucerian irony should not be taken to undermine the message of all Chaucer's religious tales. She ultimately concludes that the Man of Law is neither wholly blamed nor praised by Chaucer: see " Diversitee bitwene hir 
tale's heroine as passive or active, to determine whether she upholds an ideal of Christian femininity or whether she reflects a condemnation of medieval Christianity's tensions and its traumas. ${ }^{3}$ And more than perhaps any of the other tales, the story of Custance has called us to arms in a battle over how to read medieval texts. One camp sneers that the other is presentist and anachronistic; the other camp retaliates by implying that its foes are apologists for fourteenth-century gender and racial prejudices. The discussion can become downright nasty. But could it be that this is exactly how Chaucer wants us to behave?

Borrowing insights from the recent affective turn in literary studies, I suggest that the story of Custance is fundamentally concerned with the transmission of affect. My argument is twofold: first, that the narrative itself dramatizes how affect operates as a physical force that realigns individual and collective identities; and second, that the Man of Law's narration, combined with the other pilgrims' reactions in the Epilogue, models how affects can leap between narrative worlds and between communities. The Man of Law, as I will demonstrate, "catches" affect from his characters, and the other pilgrims in turn become infected by the affect of the tale-teller. Though my suggestion that Chaucer predicts our modern disputes over his text is tongue-in-cheek, I do believe that he intends for readers to catch affect from the tale-and that in the Epilogue's enactment of audience response, we see him testing out possibilities for how readers might be moved.

\section{PRINCIPLES OF AFFECT}

My reading of the Man of Law's Tale relies on two key tenets of affect theory. One is the fundamental principle that affect is a bodily condition - a physical experience - that is transmitted from person to person and that materially changes each body it encounters. Thus,

bothe lawes': Chaucer's Unlikely Alliance of a Lawyer and a Merchant," The Chaucer Review 46, no. 1 (2011): 74-92.

${ }^{3}$ Perhaps most influentially, Carolyn Dinshaw argues in Chaucer's Sexual Poetics that Chaucer uses the Man of Law to illuminate Christian patriarchy's demands for women's ultimate passivity as objects of exchange among men: see Chaucer's Sexual Poetics (Madison: University of Wisconsin Press, 1990), 110-12. In contrast, Elizabeth Robertson suggests that Custance represents a model of femininity made possible by apostolic Christianity, and that the tale enables Chaucer "to engage with sensitive, politically charged contemporary religious controversies, especially those raised by Lollardy, without specifying his own religious commitments" ("The 'Elvyssh' Power of Constance: Christian Feminism in Geoffrey Chaucer's Man of Law's Tale," Studies in the Age of Chaucer 23 [2001]: 148). 
individuals, crowds, and whole communities can change in subtle and not so subtle ways through the sharing of affect. Second, and even more important, affect is unpredictable and uncontrollable: we can and do endeavor to steer one another's affective responses toward particular ends, but affect retains the potential to elude any attempt at channeling or containment. Both of these principles have been articulated by recent affect theory, but as medievalists understand, both also have premodern antecedents. While Chaucer would not have shared the epistemological frameworks within which today's affect theorists operate, his contemporaries did actively theorize the physical transmission of feeling from person to person, and of course the difficulty of predictably steering affect was also well known. ${ }^{4}$

Affect itself is understood as a physical sensation prior to conscious perception: something experienced in the body before the mind processes that something into a particular emotion. It is "a non-conscious experience of intensity; it is a moment of unformed and unstructured potential" which, when later converted into a conscious "emotion," serves as "the body's way of preparing itself for action in a given circumstance by adding a quantitative dimension of intensity to the quality of an experience." ${ }^{5}$ Affect primes us for action-but the actions we take are open-ended, shaped by the individual emotions we assign to the intensities we experience. The unpredictability of affective potential multiplies, furthermore, when affect is transmitted from body to body, with each person assigning her own emotional interpretation and each subject framing her own set of responses or actions. Social psychologists like Teresa Brennan call the process of affective sharing "entrainment," understood technically as "the process whereby human affective responses are linked and repeated. ${ }^{\circ 6}$ Today's affect scientists believe that

\footnotetext{
${ }^{4}$ I am not the first to note this kinship between medieval and modern views of affective transmission, though in general medieval studies has been slower to engage the recent affective turn than some subfields of the Humanities. (Beyond, that is, our ongoing engagement with affective piety, which in fact began before the affective turn itself and uses "affect" in a somewhat different sense.) For some recent contributions to the affective turn in medieval studies, see Holly Crocker, "Affective Politics in Chaucer's Reeve's Tale: 'Cherl' Masculinity after 1381," Studies in the Age of Chaucer 29 (2007): 225-58; Steele Nowlin, "The Legend of Good Women and the Affect of Invention," Exemplaria 25, no. 1 (2013): 16-35; Stephanie Trigg, ed., "Premodern Emotions," special issue, Exemplaria 26, no. 1 (2014).

5 Eric Shouse, "Feeling, Emotion, Affect," M/C Journal 8, no. 6 (2005). http://journal.media-culture.org.au/0512/03-shouse.php.

${ }^{6}$ Teresa Brennan, The Transmission of Affect (Ithaca: Cornell University Press, 2004), 52.
} 
bodies entrain one another through touch, hearing, and sight, but Brennan stresses that bodies also and most importantly entrain one another chemically. For example, an angry body exudes pheromones that are produced in response to feeling anger. ${ }^{7}$ Bodies which draw near to this angry body absorb the chemicals of anger, physically taking in the affective residue through a sensory process Brennan calls "unconscious

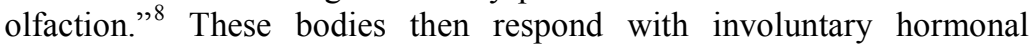
changes to align themselves with the newcomer's affect. Brennan cautions that the newly entrained bodies may translate affective potential into any type of emotion, creating different personal interpretations to name a single shared intensity. ${ }^{9}$ The important principles to note here are that bodies physically change one another in response to sensations which become emotions, and that the personal dimensions of interpretation enhance the unpredictability of affect, even if the fact of transmission itself is a physiological given.

Chaucer's contemporaries would not be surprised by this theory that bodies exert a physiological pull on one another. Indeed, in some ways Brennan's descriptions of unconscious olfaction sound not unlike the theories of optics that sought to explain how sinful desires travel from person to person. A representative example comes from Peter of Limoges' influential thirteenth-century De Oculo Morali, an optics manual for preachers:

[I]t seems probable that when a woman looks at a man lustfully, the lustful vapor emanating from her heart rises to her eyes, infecting the woman's visual rays. Thus infected, the rays travel to the man's eyes (assuming that we see by extramission) and when they arrive at the man's eyes and infect them, the infection passes to the man's heart, just as it proceeded from the woman's heart first. ${ }^{10}$

Here, optical rays take the place of modern pheromones, but the mechanics of transmission are similar. The affect of lust travels, unbidden, from the woman to her male observer; the woman exerts no

\footnotetext{
${ }^{7}$ Pheromones, Brennan explains, are not only associated with aggression and sexual behavior, though these are the two arenas in which they have been most studied. A pheromone, generally, is one of a class of "molecules that can be airborne and that communicate chemical information" and that "produce reactions by unnoticeable odor in many hormonal interactions" (9).

${ }^{8}$ Brennan, 13.

${ }^{9}$ Brennan, 7.

${ }^{10}$ Peter of Limoges, The Moral Treatise on the Eye, trans. Richard Newhauser (Toronto: Pontifical Institute for Medieval Studies, 2012), 99.
} 
agency in sending forth these lust-rays, nor does the man willingly accept them into his eyes, where they transform his body to match her lust. Peter later stresses the importance of stealing not a single glance at a woman, so great is the danger of becoming entrained. ${ }^{11}$ Affect in both theories has a radical power to reshape individual desires - and consequently the relationships among individuals in communities. ${ }^{12}$ And, of course, affect in both cases remains fundamentally unpredictable, detached as it is from any agency on the part of the transmitting or receiving bodies. ${ }^{13}$

This uncontrollability of affect grows in response to the fact that affect itself can proliferate wildly. In the process of traveling beyond the bounds of the transmitting body, it generates a surplus of intensity, a free-floating "something extra" which is not safely integrated as part of the conscious self until it is processed into emotion. Sara Ahmed offers the trenchant analogy of affective proliferation as an "economic" process, wherein "affect does not reside positively in the sign or commodity, but is produced as an effect of its circulation." 14 Emotions become attached to cultural products, including texts, and the circulation of those commodities builds the force of affect while also working to associate or attach affective resonances to groups of people within society. We enact this process whenever we draw another's attention to something which has provoked an affective response within ourselves, perhaps introducing the object in question with an incredulous "did you hear that?" or an indignant "well, would you take a look at that!" The surplus is created in the act of reaching out for an affective response: an intensity has arisen,

\footnotetext{
${ }^{11}$ Peter of Limoges, 100-04.

${ }^{12}$ Peter's description of entrainment is not the only medieval theory that resembles modern affective transmission. For instance, we also find medieval discourses on lovesickness that draw upon Latin, Arabic, and Greek medical treatises to describe something akin to entrainment. John Livingston Lowes explains one example, the amor hereos of Chaucer's Arcite in the Knight's Tale, which is partially indebted to Avicenna's concept of al-ishq: a notion which has been taken to describe lovesickness in particular, but which also meant for Avicenna a broader set of "mysterious forces which make things strive to come together" ("The Loveres Maladye of Hereos," Modern Philology 11, no. 4 [1914], 530).

${ }^{13}$ As scholars have shown, other senses beyond sight also appear in medieval texts as vectors that bring bodies together and influence emotion. Katelyn Robinson calls us to witness the many saints' lives and other religious texts attesting the power of smell in broadcasting holiness and propagating holy emotions ("The Anchoress and the Heart's Nose: The Importance of Smell to Medieval Religious Women," Magistra 19, no. 2 [(2013]). For an even broader overview of medieval thinking on bodily porousness and the influence of individual bodies on one another's emotions, see Heather Webb, The Medieval Heart (New Haven: Yale University Press, 2010).

${ }^{14}$ Sara Ahmed, The Cultural Politics of Emotion (New York: Routledge, 2004), 45.
} 
but for the barest moment it has not yet been absorbed or interpreted by a new body. It is as yet unstable, and full of potential, both for good and for ill. ${ }^{15}$ Indeed, Ahmed suggests that within communities, we are constantly engaged in efforts to "stick" particular affects to particular people, and the emotionally-charged language of a text can function as a kind of adhesive. ${ }^{16}$ Our hope-operating beneath the level of conscious desire - is that by sticking affects and their attendant emotions to some people, and not to others, we can isolate ourselves from bad feelings and hold ourselves closer to good feelings. ${ }^{17}$ Yet a difficulty arises: because of the economic nature of affective circulation, there is always too much feeling, more than enough to go around. This surplus retains its potential to become anything once it has been absorbed by a new body, processed into an emotion, and "stuck" to a target which represents in the feeling subject's mind the source of the emotion. The surplus remains unpredictable and uncontrollable, which constitutes both the promise and the peril of affect.

The Man of Law as a narrator displays a great deal of ambivalence about the affective dimensions of his narrative. That the story of Custance relies heavily on pathos has become a critical commonplace, but what has been less fully scrutinized is how the Man of Law vacillates between encouraging pathos - demanding affective participation from his audience - and struggling to divest that pathos of power by redirecting his audience's attention toward the twin forces of God and fate. Critics

${ }^{15}$ If, for example, I ask my interlocutor to share my outrage at something I have just heard on the news, and if she becomes entrained by my bodily sense of agitation but instead applauds the broadcast that has offended me, she feels united with the broadcaster and repelled from me- but with the same intensity of force that I feel.

${ }^{16}$ Ahmed, Cultural Politics of Emotion, 13.

${ }^{17}$ As a particularly troubling example of how texts strive to organize communities through sticky affects, Ahmed analyzes a series of speeches on asylum seekers, delivered in 2000 by then-leader of the UK Conservative Party, William Hague. Ahmed highlights how Hague deploys language associated with fear and loss of control: words like 'flood' or 'swamped' feature prominently to create "the anxiety of being overwhelmed by the actual or potential proximity of others" (Ahmed, 46). Yet the same speeches insist upon hospitality as a core British value, one that rightly aids legitimate refugees but can be easily exploited by so-called "bogus" asylum-seekers. As Ahmed explains, "the figure of the bogus asylum seeker evokes the figure of the 'bogey man,' as a figure that stalks the nation and haunts its capacity to secure its borders. The 'bogey man' could be anywhere and anyone; a ghost-like figure in the present, who gives us nightmares about the future, as an anticipation of a future injury" (Ahmed, 47). The speeches purport to create a named, knowable Other: one who is not British, who seeks asylum, and who does so fraudulently. Yet the affective surplus proliferates because the Other in question is not so easy, in reality, to define. The surplus remains as a potential threat for the future, and the psychic space of national identity that Hague seeks to defend is left no more secure than before. 
have tended to treat the Man of Law as a voice for order: he is an advocate for patience, a promoter of providence, and a defender against the forces of dissent that seethe under the surface of the well-ordered society. ${ }^{18}$ Putting a finer point on the nature of the order that this narrator craves, Susan Schibanoff, Kathy Lavezzo, and others have illuminated how the Man of Law's own emotional outbursts-especially against Custance's devious mothers-in-law-buttress the twin ideologies of Christianity and patriarchy that most profoundly structure his world. ${ }^{19}$ However, it is important to note that Chaucer gives us a narrator who does not lose his composure exclusively in moments of anger. To the contrary, the Man of Law becomes similarly disordered by joy and grief, as I will demonstrate below. If we attend more closely to the range of affective responses the Man of Law displays to his own tale, we see that the problem of the affective surplus is truly at the heart of this text.

\section{TOO MUCH OF A GOOD THING}

A pattern of proliferating affect emerges across the first two major episodes in the Man of Law's Tale, as Custance journeys from Rome to Syria and then to Northumbria. As Custance leaves Rome and travels to Syria, she exudes love and transmits this affect to others. In the deeply

\footnotetext{
${ }^{18}$ Gerald Morgan is on the side of providence, arguing that while the Man of Law "challeng[es]" readers with the discomfort of this doctrine, he also leads the audience to feel that "the alternative [to believing in providence] is to accept the meaninglessness of the pattern of external events in relation to individual experience, and that is hardly less difficult to accept" ("Chaucer's Man of Law and the Argument for Providence," Review of English Studies 61, no. 248 [2010], 29). Taking a different approach to the question of order in the tale, Susan Nakley suggests that the Man of Law uses the construct of the nation to resolve various kinds of disorder that threaten the margins of his tale: "He ultimately presents an historical case for national sovereignty as the antidote to the problems plaguing England, its language, and its institutions of marriage, Church, and Law" ("Sovereignty Matters: Anachronism, Chaucer's Britain, and England's Future Past," The Chaucer Review 44, no, 4 [2010], 369).

${ }^{19}$ Schibanoff argues that the tale "exposes, [and] hence questions, a central dynamic of patriarchal Christianity by which the communitas that develops in the Epilogue is achieved in response to a tale of exclusion and subordination, a tale that situates men and women, East and West, worlds apart" ("Worlds Apart: Orientalism, Antifeminism, and Heresy in Chaucer's Man of Law's Tale," Exemplaria 8, no. 1 [1996], 95). Kathy Lavezzo contends, with regard especially to Custance's eventual marriage to King Alla of Northumberland, that "Above all, the lawyer's apparent celebration of national integration via woman masks a deep antipathy to historical feminine difference. Denying women any social agency, the economy of patriarchal national fantasy subsumes woman into the body politic on a symbolic or metaphorical level" (Angels on the Edge of the World: Geography Literature and English Community, 1000-1534 [Ithaca, NY: Cornell University Press, 2006], 106).
} 
pious context of the tale, the love Custance radiates is best understood as caritas; most characters perceive her as embodying a spirit of goodness and generosity, as well as love for her fellow man, and in most cases her love for others draws those others closer to the Christian God. In both of these first two episodes, however, the surplus of caritas becomes unstable. In each location Custance encounters characters who feel her intensity not as love, but in a corrupted form, either as hate or lust. The Man of Law's ambivalence to affect in these first two episodes is intimately related to the religious dimensions of the love Custance exudes. Theologically, there should be no surplus of caritas, the love for one's fellow human beings in imitation of God's love for mankind. How could there ever be too much of this good thing? Moreover, the Man of Law evidently understands the importance of affect in promoting religious devotion. In a culture where affective piety was a rising trend in lay devotion, he asks his audience to become entrained by Custance in hopes that they will attach themselves to the Christian principles he himself promotes. Yet he also clearly realizes, as Patricia Gould so aptly puts it, that while affect "greases the wheels of ideology [. . . it also gums them up." 20 Once a surplus of affect has been created, it cannot easily be contained - and the first two episodes of the tale dramatize the ways in which the unstable, unpredictable intensities of affect might lead elsewhere rather than to God.

At the beginning of the Man of Law's narrative, it appears that all is well with the transmission of affect from Custance to her ever-growing crowd of admirers. The goodness of Custance floats mysteriously in the Roman air, and the people seem entranced by her good character. The Syrian merchants are surrounded by this atmosphere of caritas emanating from the as-yet-unseen and nebulous figure of Custance. "Fro day to day," the Man of Law explains, "the commune voys of every man" promotes her virtues, especially the fact that "Hir herte is verray chamber of hoolynesse, / Hir hand, minister of fredam for almesse" (II.154, 155, 167-68). The alms that Custance gives are tangible signs of her charity, but her caritas runs deeper than the material level, as evidenced by the fact that the vox populi also proclaims her humility (II.165), courtesy (II.166), and general spirit of outward-orientation toward community goals. ${ }^{21}$ I argue that we should see the Roman people

\footnotetext{
${ }^{20}$ Patricia Gould, "On Affect and Protest," in Political Emotions: New Agendas in Communication, ed. Janet Staiger, Ann Cvetkovich and Ann Reynolds (New York: Routledge, 2010), 33.

${ }^{21}$ I read this outward-orientation as well in the phrases, "To alle hire werkes vertu is hir gyde; / Humblesse hath slayn in hire al tirannye" (II.164-65).
} 
as affectively entrained by Custance. They have been fundamentally shaped by the caritas that she radiates, as evidenced by the fact that they seem to speak of nothing else; we learn of no other subject that they discuss with the Syrian merchants.

The merchants quickly become vehicles of entrainment themselves. Returning to Syria, they show that they have absorbed the affective intensity of Custance when they pass her story on to their Sultan. Summoned to relay "wondres that they myghte seen or heere" (II.182), the merchants tell the Sultan "specially" about her "greet noblesse" (II.183, 185). We see affect operating in the merchants' experience of Custance as a "wonder," or as something beyond conscious, rational explanation; they have felt her as an arresting force, and feel compelled to pass this intensity along in celebrating her noblesse. ${ }^{22}$ The Sultan, in hearing their reports,

... caught so greet plesance

To han hir figure in his remembrance,

That al his lust and al his bisy cure

Was for to love hire while his lyf may dure. (II.186-89)

He "catches" the feeling of Custance from the merchants' words, in a way that clearly mirrors the mechanics of affective transmission. Moreover, what he catches is "plesance," which, while it can indicate merely "desire" as the Riverside glosses it, can also describe "moral, spiritual, or intellectual satisfaction," as well as "delight" or a broader "enjoyment of life." ${ }^{23}$ It is my contention that all of these other meanings are at work in the Sultan's reaction - entrained by caritas, he is swept up in the intensity of Custance, to the extent that he feels a visceral aversion to the idea of remaining separated from her. What he describes is the

\footnotetext{
${ }^{22}$ For medieval readers, of course, "wonder" typically indicates something marvelous or strange, often precipitated by divine or supernatural forces. See The Middle English Dictionary, s.v. "wonder," last updated April 24, 2013, http://quod.lib.umich.edu/m/med. For modern affect theorists, wonder is linked with the affect of enchantment, a sensation that might be provoked by witnessing wonders. Jane Bennett argues that "enchantment entails a state of wonder, and one of the distinctions of this state is the temporary suspension of chronological time and bodily movement. To be enchanted, then, is to participate in a momentarily immobilizing encounter; it is to be transfixed, spellbound." Bennett, The Enchantment of Modern Life: Attachments, Crossings, and Ethics (Princeton: Princeton University Press, 2001), 5. These descriptions apply quite well to the Sultan's response, once the merchants relate the "wonder" of Custance to him: he is stopped in his tracks, as it were, immobilized and held captive by the affects that are about to change his life.

${ }^{23}$ Middle English Dictionary, s.v. "plesaunce."
} 
physical sensation that he is already part of her, so powerfully has his affect aligned his interior self with hers. Crucially, all this transpires before the Sultan even meets Custance, as a kind of love-before-firstsight. As the Sultan later tells his counselors, he must convert to Christianity and marry Custance because "I moot been hires; I may noon oother chese" (II.227). In expressing his love not as a choice, but as a fact - a feeling he must follow-the Sultan conveys his sense that at a non-rational level, his subjectivity has already been fundamentally altered by the affect that dissolves his Self into Custance.

Of course, as a sovereign the Sultan's resolution to convert is not merely an individual change of identity. Rather, he realigns his relationship to community by altering his religion to unite himself with the woman whose affect he has absorbed. Here Chaucer dramatizes how entire nations might change in the process of individuals coming to feel like one another. This, I believe, is his most striking contribution to our understanding of affect. Chaucer suggests that while the experience of affect may be momentary, the cultural aftermath can be long-lasting and consequential. Custance's conversion of the Sultan - and later in the tale, the wave of conversion she inspires in Northumbria - has also been read as a fantasy of Christian cultural expansion. Geraldine Heng, for example, proposes that here, "religious conversion is a name for the willto-power of a dominant civilization and the inflicting of its practices, institutions, and cultures upon a subordinate, recipient civilization [. . .]." ${ }^{24}$ Heng's analysis considers multiple versions of the Constance legend, including Chaucer's two sources and the anonymous King of Tars, and her insight about conversion very aptly elucidates these related texts. In Chaucer's tale, however, the dynamics of religious conversion become more tangled because Custance herself demonstrates so little evidence of a "will-to-power." Though she inspires conversions, it is difficult to see her as the covert operative of Christian cultural dominance, precisely because of the passivity that makes her, in the Man of Law's eyes, such a good Christian woman. Instead, the Man of Law's Tale illustrates something akin to what Ahmed calls the "sociality of emotions": the idea that "[i]t is through emotions, or how we respond to objects and others, that surfaces or boundaries are made: the 'I' and 'we' are shaped by, and even take the shape of, contact with others." 25 Custance leaves a trail of cultural and political upheaval behind her

\footnotetext{
${ }^{24}$ Heng, Empire of Magic: Medieval Romance and the Politics of Cultural Fantasy (New York: Columbia University Press, 2004), 183.

${ }^{25}$ Ahmed, Cultural Politics of Emotion, 10.
} 
wherever she travels; the events that follow her entry into Syria and Northumbria bear witness to how the transmission of affect realigns the relationships positioning individuals within communities. To understand how affects are shared is to understand that the boundaries of communities and nations are drawn by the things we feel together-both the things we make each other feel, and the changes we make to one another's identities through emotions. ${ }^{26}$ This process of boundary creation and re-creation is part of what makes the Man of Law so anxious about containing the affective surplus, as we will see later in the tale.

The affective nature of conversion in the Syrian episode is unique to Chaucer's version of the Constance legend. In adapting his key sourcesNicholas Trevet's version in Les Cronicles and John Gower's tale in the Confessio Amantis-Chaucer heightens the power of affect, concomitantly downplaying the spiritual and political force of Christian teaching. Gower's Constance converts the Saracen merchants with her "wordes wise"; ${ }^{27}$ when they later tell the Sultan about Constance, it is not in response to an inquiry about marvels encountered abroad, but rather to satisfy his demand that they explain why they have "here ferste feith forsake." 28 Thus, for Gower, affect is subordinated to the power of rational persuasion and Christian pedagogy, and conversion is positioned as a political trade-off between the native faith of these merchants and "[t]he rihte feith" to which they are led by reason. ${ }^{29}$ In Trevet, this dynamic is even more evident. Constance actually interrogates the merchants about their beliefs and then preaches Christian tenets until they are converted. Moreover, the conversion of the Sultan's territory is overtly politicized. We even see him handing Jerusalem, previously under his control, to Christians; he invites Christian priests to proselytize

\footnotetext{
${ }^{26}$ The force of affect in the tale of Custance exposes a point of tension in Benedict Anderson's foundational definition of the nation. Anderson calls the nation "an imagined political community" which is "conceived as a deep, horizontal comradeship" and which is also felt to be "limited" by its geographic boundaries, however much those boundaries might expand or contract. See Imagined Communities: Reflections on the Origin and Spread of Nationalism, $2^{\text {nd }}$ ed. (London: Verso, 2006), 6-7. "Comradeship" becomes in the Man of Law's Tale an affect-a flexible attachment-yet as such it disrupts the nation. When the Sultan begins to feel comradeship with Custance, his mother can no longer feel the same comradeship for him; the nation expands across its geographical boundaries by incorporating a Roman woman, yet it also affectively alienates a substantial number of subjects within those boundaries.

${ }^{27}$ John Gower, Confessio Amantis, in Sources and Analogues of the Canterbury Tales, Vol. II, ed. Robert M. Correale and Mary Hamel (Cambridge: D.S. Brewer, 2009), 606.

${ }^{28}$ Gower, 615 .

${ }^{29}$ Gower, 617.
} 
and to tear down the old temples. ${ }^{30}$ Chaucer's revision of the forces behind the Sultan's conversion, as well as the effects of that conversion, has profound implications for our understanding of the text. Stripping Custance of her role as teacher contributes to the sense of her passivity. ${ }^{31}$ Yet Chaucer also creates the powerful impression of affect as a force driving cultural change. Because we do not see Custance teaching in his text, her affective pull on other characters becomes the intangible force that explains how she catalyzes conversion.

The momentous effects of affect begin to unsettle the Man of Law when the Sultan becomes entrained, and it is here that we see the first hints of the Man of Law's ambivalence about Custance's infectious caritas. He breaks into the description of the Sultan falling in love with Custance, interrupting his narrative with a list of classical heroes and historical figures whose deaths were written in the stars. Ultimately the Man of Law suggests that the Sultan may be like one of these famous folk: the stars at his birth may have decreed that he will die for love. Nevertheless, the Man of Law himself seems unpersuaded by this explanation, introducing the theory with a hesitant "Paraventure" (II.190). He appears more confident several stanzas later, when he blames the "Crueel firmament" and the influence of Mars for sending Custance off to Syria (II.295-300). This combination of responses is revealing: the Man of Law is adamant that his audience feel the cruelty of Custance being dispatched to a foreign land, but he hedges as he ascribes her influence on the Sultan instead to the stars. I suggest that he labors to divert the audience's attention from the active role of affect in creating Custance's plight. Substituting the stars for the power of her caritas, he does diminish her feminine agency and make of her an object of exchange, but at the same time he works to contain the danger of the affective surplus by denying the power of affect to shape human actions

\footnotetext{
${ }^{30}$ Correale and Hamel translate the relevant passage thus: "And he surrendered the city of Jerusalem to the lordship of the Christians to live in, and gave liberty to the Christian bishops and their clergy to preach and to instruct the people of his land in the true faith, and to baptize, to build churches, and to destroy the temples of the idols." ("Et la cite de Jerusalem abandona a la seignurie des Cristiens pur enhabiter, et fraunchises as evesques Cristiens et a lour clergie de precher et enseigner les gentz de sa terre la droite foi, et de baptizer, et de eglises faire et les temples de maumetz destrure.") Nicholas Trevet, Les Cronicles, in Sources and Analogues of the Canterbury Tales, Vol. II, ed. Robert M. Correale and Mary Hamel (Cambridge: D.S. Brewer, 2009), 299.

${ }^{31}$ Celia Lewis argues that when Custance becomes "more remote and less active" in Chaucer's version, she also appears "more religious: a paragon of faith and purity," qualities which point to her function as a missionary figure in Syria. See "History, Mission, and Crusade in the Canterbury Tales," The Chaucer Review 42, no. 4 (2008), 366.
} 
in the first place. ${ }^{32}$ The Sultan is forced by the stars to love Custance, rather than inexorably drawn to love her by the intensity of her own affect.

When Custance arrives in Syria, we see the first truly catastrophic effects of the affective surplus, as the Sultan's mother feels this same inescapable pull of Custance and reacts violently against it. The Sultaness's own response to Custance is every bit as affect-driven as her son's, because she feels Custance as a visceral threat to the community of Syrian Muslims. If they convert to Christianity, she says, they will suffer "thralldom to our bodies and penance, / And afterward in helle to be drawe, / For we reneyed Mahoun oure creance" (II.338-40). ${ }^{33}$ Here, she conjures the image of conversion as a physical threat to the bodies of former Muslims, asking her listeners to imagine the feeling of pain these converts must experience in this life and the next. The Sultaness casts herself as the protector of these bodies, offering her own hatred for Custance as a shield against the bodily traumas of cultural change: she will "make us sauf for everemoore" and ensure that baptism "shal nat greeve us" (II.343, 352). Here, readers are reminded that, as Ahmed brilliantly articulates, hate is much like love in that each is "an intimate relationship between a subject and an imagined other, as another that cannot be relegated to the outside." ${ }^{34}$ The Sultaness feels the pull of Custance affectively, just as the other characters do; moreover, she is cognizant of the fact that in political terms, she cannot separate herself or

\footnotetext{
${ }^{32}$ A number of critics have offered important readings of Custance as an object of exchange, or as a figure whose circulation embodies various cultural forces larger than herself. Gania Barlow, for example, reads Custance as circulating spiritual authority as she travels to Syria and beyond, arguing that "the tale repeatedly equates or conflates spiritual and political authority and systems of value, making Christianity itself an enriching quality, a kind of commodity that can be circulated and exchanged to accrue power back to its 'users." See "A Thrifty Tale: Narrative Authority and the Competing Values of the Man of Law's Tale," The Chaucer Review 44, no. 4 (2010), 404-05. Francine McGregor suggests that Custance becomes trapped, in a way, by the allegorical dimensions that her character takes on: "The narrative suggests that perception's impulse toward abstraction- to seeking the universal in the particular - cripples the perceived individual's capacity to exercise selfgovernance. Chaucer explores this issue through a character who readily translates into abstraction, but who seeks to control how she is perceived so that she can have some small means of determining her own future." See "Abstraction and Particularity in Chaucer's Man of Law's Tale," The Chaucer Review 46, no. 1 (2011), 62.

${ }^{33}$ Nakley points out that the Sultaness's rhetoric of thralldom mirrors what Chaucer's readers find in the Parson's Tale, and points out that in this respect, she is "more in line with Christian views about politics, religious identity, thralldom, and the redemptive power of faith" than Custance herself ("Sovereignty Matters," 388).

${ }^{34}$ Ahmed, Cultural Politics of Emotion, 49-50.
} 
her dissident community of steadfast Muslims from her newly Christian son. This intimacy, the feeling of being relentlessly pulled toward a body that threatens her Muslim community, makes her interpret the affective power of Custance as hate, not love.

This newly retranslated affect of hate leaps across narrative boundaries in the text, crossing over into the pilgrimage frame. In the Man of Law's notorious screed against the Sultaness, Chaucer shows the narrator feeling within himself the bad feeling he imagines in the Sultaness. He feels anger, but tries to pin it to the Sultaness's body, assigning her - not Custance and not his own act of narration - as its source. The Man of Law describes the Sultaness telling a gory joke about baptism, in which she suggests that Custance will need more than a font of water to wash away the blood when she is the lone survivor of the Sultaness's massacre (II.355-57); the narrator then interrupts himself to denounce her destructive anger. He calls her, among other things, the "roote of iniquitee," a "serpent under femynynytee," and a "feyned woman" (II.358, 360, 362). Examining this moment alongside others in the tale, Schibanoff illuminates how the Man of Law aligns all women with Muslims and heretics, positioning all three categories as dangerously proximate Others, in order to create a "privileged defensive wall" around Christian men. ${ }^{35}$ I would push this point a step further, arguing that the Man of Law not only struggles against particular groups of nameable Others. He also fights to control the very force of affect itself: its unpredictable ability to transform selves into Others, and vice versa, denying any future hope for stability inside any kind of ideological "defensive wall." The Sultaness's refusal to feel Custance's affect as caritas creates a surplus, now transformed into hate; the Man of Law tries to spend down this surplus by insisting that the hate radiated by the Sultaness must attach itself only to her own body, without spreading further throughout the community. By trying to "stick" hate to a concrete Other, the Man of Law labors to confine the unpredictable operation of the surplus, which otherwise threatens to continually redefine community.

Here, we see Chaucer testing out one way that narrative might function in constructing, policing, or testing the boundaries of communities. The Man of Law acts out the process of "reading" a text in the process of narrating it, and thus models how a reader might respond when feeling threatened by even a fictional representation of a challenge to his own community's values. Having become swept up in a tale whose

\footnotetext{
${ }^{35}$ Schibanoff, "Worlds Apart," 96.
} 
earliest moments imagine the triumph of Christian ideals, as promoted through caritas as an affect, the Man of Law becomes ambivalent when his text forces him to envision the limits of this triumph. Rather than questioning Christianity itself, or questioning the value of caritas, the Man of Law attempts to confine the unpredictable affective effects of Custance by assigning hatred only to the Sultaness.

Once the cycle of surplus-creation begins, it is difficult to forestall; indeed, the cycle soon repeats itself in the next section of the narrative. Post-massacre, the Sultaness sends Custance out to sea in a rudderless ship and Custance eventually lands in Northumbria, where her caritas once again begins entraining the populace. Having been taken in by the Constable and his wife Hermengyld, Custance "was so diligent, withouten slouthe, / To serve and plesen everich in that place / That alle hir loven that looken in hir face" (II.530-32). Here, we find Custance radiating caritas and while the Northumbrian populace clearly appreciates her diligent service for her new community, the people are simultaneously moved by the less rational, less intentional force of affect. Instantly upon looking in her face, the Northumbrians love her; because the Man of Law has not mentioned her physical beauty for quite some time, their reflexive attraction to her seems more a sign of entrainment than of admiration for her physical features. Indeed, Hermengyld quite soon converts to Christianity, in part through Custance's prayers but also because she "loved [Custance] right as hir lyf" (II.535). Much like the Sultan, who so powerfully felt like Custance that he changed faiths to align his religious identity with hers, Hermengyld also takes up a new religion that better reflects her affective oneness with Custance.

The surplus of affect once more becomes unstable, however. One wicked knight feels pulled by Custance as his fellow Northumbrians do, but he senses this attraction as lust rather than caritas: he begins to "Love hir so hoote, of foul affeccioun, / That verraily hym thoughte he sholde spille, / But he of hire myghte ones have his wille" (II.586-88). It is important to note that, with the exception of the detail that this knight's love is "foul," his sense of being pulled by Custance quite closely mirrors the Sultan's process of falling in love with her; the Sultan, like this knight, also felt like Custance so strongly that he was convinced he would die without her. Thus, we find the surplus has once again run out of control. The wicked knight feels the same attraction the other Northumbrians feel, yet the nature of the intensity he feels is disruptive to Christian tenets of virtue. The Man of Law endeavors to contain the surplus at this moment by suppressing the knight's connection with the Sultan and attributing the knight's lust to Satan, whose hatred of 
Custance's perfection makes him intent on thwarting her (II.582-84). Up to this point in the Northumbrian episode, the Man of Law has encouraged his audience to admire Custance's power to move others affectively; yet here, he firmly denies that she has moved the wicked knight at all.

The Man of Law assigns both the knight's lust and the Sultaness's hatred to Satan, and in this shift in attribution of power, we see the further evidence of his ambivalence about affect. This is not to say that the Man of Law, or indeed Chaucer himself, does not actually credit the notion of diabolical influences on human lives. Rather, I suggest that Chaucer shows us one possible readerly response to the discomfort of the affective surplus at this moment. The Man of Law faces the unpleasant cognitive challenge of acknowledging that caritas, promoted in the Christian worldview as the most powerful positive affect available to mankind, nevertheless has the power to go awry and to sow both discord and sin. When he "sticks" lust to Satan, denying its kinship with the caritas that entrains Custance's other followers, the Man of Law models how a reader might try to stabilize his own ideological grounding in the world by stepping back from the power of affect and attempting to limit its circulation.

Nevertheless this gesture of deflection does not remove the Man of Law from the anxious circuit of thought in which he has evidently become enveloped. What follows - the knight's murder of Hermengyld and Custance's trial for the crime-is the section of the tale which most powerfully displays the Man of Law's ambivalence while also most wrenchingly calling for the audience's affective participation in the text. Throughout his narration of Custance's trial, the Man of Law highlights the Northumbrians' love for Custance and their firm belief in her innocence. These sentiments extend even to King Alla, who directs the trial proceedings. Upon hearing how the accused had first washed up on Northumbrian shores, Alla feels her misfortunes in a visceral way: "The kynges herte of pitee gan agryse, / Whan he saw so benigne a creature / Falle in disese and in mysaventure" (II.614-16). Pulled by the force of Custance, feeling her caritas as benignity, his heart actually trembles. Notably, the feeling of being affectively moved by her precedes his conscious interpretation of what she signifies for his community. Soon afterward he is similarly moved by "the greet moornyng / Among the peple" who do not believe Custance is guilty (II.621-22). The king responds to the people's grief, an emotion itself stoked by the fact that they have felt Custance "loving Hermengyld right as hir lyf" (II.625). Pulled close to Custance, the Northumbrian people feel her pain, and the 
king "caught a greet motyf / Of this witnesse" (II.628-30). Alla resolves to investigate further, yet the Man of Law, despite having narrated all of this with such great affective force, denies his audience the opportunity to trust that all will be right for Custance. Instead, he keeps alive the notion that affect will be contained, that the affectively moved king and people will fail to act upon their state of feeling like Custance.

Here, the containment of affect and the rescue of his heroine become two goals in opposition to one another, and the Man of Law models the discomfort of working through this paradox. In apparent contradiction of Custance's power to move the masses, the Man of Law staunchly insists that she is condemned, powerless, and about to die. Only Christ can help her, he says; yet, despite his steadfast faith in providence, the Man of Law is still pained by Custance. He asks the audience to absorb some of this pain from him as Custance travels toward what he casts as her impending execution:

Have ye nat seyn somtyme a pale face,

Among a prees, of hym that hath be lad

Toward his deeth, wher as hym gat no grace,

And swich a colour in his face hath had

Men myghte knowe his face that was bistad

Amonges alle the faces in that route?

So stant Custance, and looketh hire aboute. (II.645-51)

This passage has fascinated critics, and for good reason. The Man of Law solicits our attention directly with the second-person address, "Have ye nat seyn," and he implores the audience to reflect upon the shared experience of witnessing public executions. The appropriate response is to reach deep within personal memory and to call up some of the most traumatic bodily sensations available to living humans, those sensations associated with witnessing a fellow life at its limits. ${ }^{36}$ The Man of Law suggests that the visceral sense of fear that rules the body of the condemned produces an unmistakable paleness; if this stanza succeeds, the audience might perhaps blanch alongside the heroine, becoming

\footnotetext{
${ }^{36}$ McGregor argues that this moment in the text "offers a nuanced conflation of generalizing and particularizing directives," because it situates Custance as a type of the suffering individual, but also individualizes her suffering as a participant in this category; she also notes that the sight of the suffering Custance "is meant to evoke empathy rather than awe or desire" ("Abstraction and Particularity," 72). This insight is germane to my reading of how affect operates at this moment in the text, though I would add that empathy in this case derives from our sharing of Custance's affect. We are meant to become the suffering figure ourselves, by remembering the feeling of suffering alongside others we have seen.
} 
visibly more like her as they absorb her sense of horror in anticipation of witnessing a gruesome failure of justice. The Man of Law issues a fervent plea for noblewomen in particular to be moved by Custance, and soon afterward he shows Alla moved by this very scene as well. Nevertheless, the narrator's ambivalence about the force of affect remains on display. Despite seeing Alla moved by Custance, despite potentially feeling moved themselves, the audience finds the Man of Law insisting upon the futility of affect. It is important to him that the audience feels the pain of Custance, but it is equally important to submit to the knowledge that none but God can help her.

This help does arrive through a miracle in the next few stanzas. The vicious knight perjures himself in swearing upon a book of Gospels, a mysterious hand smites him, and a voice rings out to condemn him for slandering Custance, an innocent daughter of the Church. The affect of wonderment having replaced sorrow in their hearts, the Northumbrians convert to Christianity and the Man of Law cheers, "thanked be Cristes grace!" (II.685). The miracle obscures what the Man of Law has insisted upon earlier in the trial episode: that the Northumbrians already love Custance so much that they believe her innocence, and that Alla was powerfully moved by his own sense that Custance feels too good to be a murderer. Alla is so moved, in fact, that even as a pagan he called for the Gospel book, inviting divine intervention and precipitating the miracle. Eliding the force of affect and redirecting the audience to feel awestruck by God's power instead of Custance's goodness, the Man of Law once more attempts to control the slippery affective surplus which he formerly encouraged through his solicitations of audience sympathy.

The remainder of Custance's travels offer no more promise of a tidy resolution for readers. Thus, readers who comply with the Man of Law's paradoxical demands agree to inhabit a difficult affective position themselves. Those who take seriously the narrator's invitation to become affectively moved by Custance, yet also follow his didactic exhortation to cultivate resignation, consent to share the narrator's frustration with the dual promise and threat of affect. In this sense, I believe we can see Chaucer offering the audience an affective challenge of our own. He invites us to study the Man of Law's agonized negotiation of affect, his ongoing uncertainty of how much to embrace its power and how much to limit its threats. Spearing warns that if we attend closely to the narrator's behavior, as I am suggesting we do here, modern readers risk losing Chaucer's most important lesson about the difficulty of confronting 
injustice and hardship in a world supposedly governed by providence. ${ }^{37}$ But I would counter that in fact, the narrator's turmoil actually highlights these philosophical difficulties. By presenting this tale as voiced by a very complex, very human narrator, who shares with readers the universal bodily experience of affect, Chaucer forces the audience to interrogate our own affective investments in the text and in the questions of justice and fate that it poses.

\section{NO END IN SIGHT}

The core narrative of the Man of Law's Tale becomes tidier when Custance reaches Rome, adhering closely to familiar patterns of homiletic romance. ${ }^{38}$ Despite the conventionality of the plot, however, the Man of Law is moved intensely by each moment he relates. Beset by extremes of grief and happiness, he even professes difficulty in continuing with the tale. Witness this extraordinary stanza, where the Man of Law begs for relief from the pathos of the reunion between Custance and Alla:

Long was the sobbyng and the bitter peyne,

Er that hir woful hertes myghte cesse;

Greet was the pitee for to heere hem pleyne,

Thurgh which pleintes gan hir wo encresse.

I pray yow alle my labour to relesse;

I may nat tell hir wo until to-morwe,

I am so wery for to speke of sorwe. (II.1065-71)

As though he has been entrained by the same mournful cries that he asks his audience to hear, the Man of Law feels his own sorrow "encresse" and he craves respite from this sensation. ${ }^{39}$ He keeps speaking, though,

\footnotetext{
${ }^{37}$ Spearing, Textual Subjectivity, 133-36.

${ }^{38}$ Custance is reunited with Alla and with her father; her noble status is restored and soon her son Maurice inherits his rightful title as Emperor of Rome; Alla and then Custance both end their lives in quiet virtue. I borrow the label "homiletic romance" from Dieter Mehl, who uses it to describe texts, including several in the Constance group, where characters are not saints, but behave in a saintly fashion. In many of these narratives, a virtuous Christian heroine maintains her faith steadfastly throughout unthinkable trials, and is eventually rewarded with earthly joys, rather than the martyrdom that would be gained by a true saint. Mehl, The Middle English Romances of the Thirteenth and Fourteenth Centuries (London: Routledge and Keegan Paul, 1968), 121.

${ }^{39}$ Indeed, the Man of Law is momentarily blind to the happiness of this moment, and only after a break does he acknowledge the couple's "blisse" second only to "the joye that lasteth everemo" (II.1075, 1076). I thank Alison Langdon for the observation that this pause between grief and joy enhances the sense of affective surplus: the Man of Law can
} 
and soon finds himself similarly unable to express the joy his characters feel when Custance presents herself to her father. The Man of Law asks, "Who kan the pitous joye tellen al / Bitwixe hem thre, syn they been thus ymette?" (II.1114-15). Though the excess happiness causes him less discomfort than the earlier onslaught of grief, the Man of Law is nevertheless silenced by it. He resolves to "make an ende" of his tale, and does indeed draw the narrative to a speedy conclusion shortly thereafter (II.1116). ${ }^{40}$

Still, the tale appears to remain finished for only a moment before we observe the rogue force of affect bleeding into the Canterbury frame narrative. In the Epilogue to the tale, the pilgrims display a range of possible affective responses that audiences might experience, including excitement, anger, and unease. As I engage with this ongoing affective disruption in the Epilogue, I am inspired by Anne McTaggart's call to read Chaucer as an early "anthropologist of emotion," a cultural observer with an abiding fascination for the power of art to construct emotionswhich in turn influence real human actions. ${ }^{41}$ If the Man of Law's Tale is an anthropological study in both the power of affect and the ambivalence provoked by the recognition that affective force is impossible to steer, the Epilogue dramatizes one more test case: the extension of the experiment to the new "society" of the Canterbury pilgrims, who exist outside the tale itself but who are pulled by its affects. ${ }^{42}$ As is typically the case, Harry Bailey is the pilgrim most visibly transported by what he has heard; indeed, affect moves his body as he spontaneously bursts into action and speech. Geffrey relates, "Owre Hoost upon his stiropes stood anon, / And seyde, 'Goode men, herkeneth everych on! / This was a

acknowledge happiness only through a spiritual comparison, and even then only after separating himself from grief.

${ }^{40}$ It is worth noting that when she returns to Rome once more after Alla's death, Custance's charity is safely limited to material acts of alms-giving, and we hear no more about popular acclaim for her goodness. It seems that in the end, she no longer produces the kind of affective surplus that once changed nations in her wake.

${ }^{41}$ Anne McTaggart, Shame and Guilt in Chaucer (New York: Palgrave Macmillan, 2012), 5 .

${ }^{42}$ For those who wish to find unity in the order of the Canterbury Tales, the Man of Law's Epilogue is problematic, in part because it accompanies the tale in just over half the extant manuscripts: Patricia Eberle notes 35MSS with the Epilogue, 22 without. See her notes to the tale in The Riverside Chaucer, 862. Derek Pearsall declares that "Though [the Epilogue] was intended by Chaucer at one point as a link, he did not make up his mind what was to follow, and after toying with various possibilities he abandoned it." See Pearsall, The Canterbury Tales, 20. My reading of the Epilogue takes it as a snapshot of one stage in Chaucer's "toying" with the order of the tales, and examines what this configuration of text, narrator, and pilgrim-interlocutors might accomplish. 
thrifty tale for the nones!'” (II.1163-65). The Host appears to erupt into the air, standing up out of his saddle and imploring the other pilgrims to become entrained as he has been-"herken" having the dual valence of "to listen" and "to take heed." ${ }^{43}$ Here, he demonstrates the violence with which affects may be transmitted, and the as-yet unreasoned, uncalculated actions they may provoke.

The exchange that follows has become infamous among Chaucerians, in part for the vehemence with which each character reacts to the others' behavior. Harry Bailey charges the Parson with telling the next tale, swearing "by Goddes dignitee!" that it is sure to be an edifying contribution; the Parson objects to his language, exclaiming, "Benedicite! / What eyleth the man, so sinfully to swere?" (II.1169; II.1170-71). The Host, unabashed, sneers "I smelle a Lollere in the wynde" (II.1173). Finally, the Shipman intervenes to preemptively silence the alleged heretic's tale, counteroffering a story from his own "joly body" that will "waken al this compaignie" (II.1185-87). Reading this exchange in terms of affect, we find the characters acting out a dynamic not unlike what we observed in the tale itself. The Host radiates excitement, and the Parson feels pulled by it, but unwillingly. His words seem to burst forth from him just as reflexively and just as intensely as the Host's, his "Benedicite!" signaling that he has felt the Host's excitement as a threat, an uncomfortable disruption of his own body. When the Parson moves beyond his initial exclamation to ask what "ails" the host, we see him at the stage of consciously processing affect, filtering it through his personal experiences in the world and his cultural or ideological investments as a member of the clergy. In the split second of processing, the Parson puts words to his visceral sense of discomfort with the Host: this man's intense, immoderate affects are a disease of the soul, and one that threatens to corrupt others as well. In labeling the Host's conduct sinful, the Parson tries to guard against the spread of sin by sticking the surplus intensity back to what he perceives as its origin. This man is a blasphemer, he says, asking the other pilgrims to attach to Harry Bailey the same feeling of aversion that the Parson himself feels.

It is significant, as well, that the Shipman rises to defend excess intensity, flouting the Parson's deflection of the affective surplus. Once he has been labeled a Lollard by the Host - a gesture through which Harry Bailey refuses to have bad affects "stuck" only to himself - the Parson becomes a threat of two kinds. Yes, he threatens discord through heterodoxy, but the Shipman's promise of a jolly and invigorating tale

\footnotetext{
${ }^{43}$ Middle English Dictionary, s.v. "herken."
} 
suggests there is another layer of significance at work here, too. The Shipman apparently believes that to facilitate the pleasurable circulation of affects among the compaignye, "preaching" must be forestalled. When the Host calls for the Parson to preach, the Shipman bursts out, "Nay, by my fader soule, that schal he nat!" / [...] "Heer schal he nat preche; / He schal no gospel glosen here ne teche" (II.1178-80). The Shipman himself is clearly moved in a bodily, affective manner, judging from the frenetic, repeated insistence against preaching; he offers his own body as a tool for perpetuating what he sees as a pleasurable variety of affective chaos, and as a shield against the discordant affects that might arise from a Parson who could "sowen som difficulte" with his preaching (II.1183). Interestingly, when the Parson does take his turn at the end of the Canterbury collection, he reveals that preaching, rather than sowing discordant affects, is a genre dominated by logic rather than affect; nevertheless, even in this sense the Parson's sermon stands opposed to the kind of tale the Shipman offers to tell, one which he vows will contain neither philosophy nor Latin (II.1190).

\section{CONCLUSION}

I propose that in the Epilogue we witness Chaucer testing out the notion that literature can entrain its audience, and that the audience might carry forth the affective surplus of a text to instigate any number of real world actions. Each of the pilgrims has heard the same tale, but fashions a different response to the sensations it engenders; these sensations are used to label others by the reactions they display to the affects they feel. In Harry Bailey's case, his love for the tale manifests itself as an enthusiasm that demands others mirror the same emotion. For the Parson, the important precept is to limit the disruption that the Host's excessive display of love for the tale might cause (in this way, he seems an astute reader of the problem of caritas in the tale itself). The Shipman, finally, manipulates affect in another way, trying to keep the surplus in play as a revitalizing force that he hopes will "wake" or animate the travelers. This collection of responses suggests for Chaucer's readers-medieval and modern - a number of ways that one might react to the feeling of reading a text. The overriding message is not necessarily that any given response is right or wrong, but more that we must attend to the ways in which texts move us, and the ways that our own affects, if we are entrained, might shape our position in the communities we inhabit. In fact, we might say that Chaucer teaches us to be more astute readers, by making us mindful 
of reading as an affective activity that absorbs our bodies as well as our minds and thus redounds on real life.

This lesson remains a pertinent one for Chaucer's readers today, including the critics whose discord over the Man of Law's Tale I addressed in opening this essay. Could the affective surplus be a contributing factor in some readers' unease or emotional dissatisfaction with the tale? The Man of Law abets this surplus by asking us to feel for Custance in particular ways, yet just as insistently denies us the opportunity to indulge in this affect by redirecting our attention to providence. What Carolyn Dinshaw calls the "fundamental instability" and "hollowness of the extreme pathos" in the tale need not indicate a flawed narrator or an ironic stance taken by Chaucer himself. ${ }^{44}$ To some readers, the story of Custance may indeed feel hollow, an ostensible tearjerker that nonetheless leaves them dry-eyed and bereft of cartharsis. With these readers, the Man of Law has succeeded - at least to some extent - in controlling the surplus. Others, however, are genuinely moved by the tale's pathos, and with these readers, the affective surplus retains the potential to shape hearts and minds. In the long run, there is little to be gained by debating which emotional responses to the tale are most "correct." Instead, I suggest that we might focus more deeply on Chaucer's invitation to reconceptualize the act of reading. He paints a striking portrait of what might happen when readers feel differently about a text: in so doing, he calls us to imagine reading as an act of feeling, and reading together as a process of feeling about community.

\section{Wilmington College}

\footnotetext{
${ }^{44}$ Dinshaw, "Pale Faces: Race, Religion, and Affect in Chaucer's Texts and Their Readers," Studies in the Age of Chaucer 23 (2001), 24.
} 


\section{Bibliography}

Ahmed, Sara. The Cultural Politics of Emotion. New York: Routledge, 2004.

Anderson, Benedict. Imagined Communities: Reflections on the Origin and Spread of Nationalism. $2^{\text {nd }}$ ed. London: Verso, 2006.

Barlow, Gania. "A Thrifty Tale: Narrative Authority and the Competing Values of the Man of Law's Tale." The Chaucer Review 44, no. 4 (2010): 397-420. http://dx.doi.org/10.5325/chaucerrev.44.4.0397

Bennett, Jane. The Enchantment of Modern Life: Attachments, Crossings, and Ethics. Princeton: Princeton University Press, 2001.

Brennan, Teresa. The Transmission of Affect. Ithaca: Cornell University Press, 2004.

Chaucer, Geoffrey. The Canterbury Tales, in The Riverside Chaucer, edited by Larry D. Benson. $3^{\text {rd }}$ ed. Boston: Houghton Mifflin, 1987.

Correale, Robert M., and Mary Hamel, eds. Sources and Analogues of the Canterbury Tales. Volume II. Cambridge: D.S. Brewer, 2009.

Crocker, Holly. "Affective Politics in Chaucer's Reeve's Tale: 'Cherl' Masculinity after 1381." Studies in the Age of Chaucer 29 (2007): 225-58.

Dinshaw, Carolyn. Chaucer's Sexual Poetics. Madison: University of Wisconsin Press, 1990.

- "Pale Faces: Race, Religion, and Affect in Chaucer's Texts and Their Readers." Studies in the Age of Chaucer 23 (2001): 19-41.

Gould, Deborah. "On Affect and Protest." In Political Emotions: New Agendas in Communication, edited by Janet Staiger, Ann Cvetkovich, and Ann Reynolds, 18-44. New York: Routledge, 2010.

Hendrix, Laurel. "'Pennannce profytable': The Currency of Custance in Chaucer's Man of Law's Tale." Exemplaria 6, no.1 (1994): 141-66. http://dx.doi.org/10.1179/exm.1994.6.1.141

Heng, Geraldine. Empire of Magic: Medieval Romance and the Politics of Cultural Fantasy. New York: Columbia University Press, 2004.

Lavezzo, Kathy. Angels on the Edge of the World: Geography, Literature, and English Community, 1000-1534. Ithaca, NY: Cornell University Press, 2006.

Lewis, Celia. "History, Mission, and Crusade in the Canterbury Tales." Chaucer Review 42, no. 4 (2008): 353-82. 
http://dx.doi.org/10.1353/cr.0.0003

Lowes, John Livingston. "The Loveres Maladye of Hereos." Modern Philology 11, no. 4 (1914): 491-546. http://dx.doi.org/10.1086/386943

Lynch, Kathryn. “'Diversitee bitwene hir bothe lawes': Chaucer's Unlikely Alliance of a Lawyer and a Merchant." The Chaucer Review 46, no. 1 (2011): 74-92.

McGregor, Francine. "Abstraction and Particularity in Chaucer's Man of Law's Tale." The Chaucer Review 46, no. 1 (2011): 60-73.

McTaggart, Anne. Shame and Guilt in Chaucer. New York: Palgrave Macmillan, 2012. http://dx.doi.org/10.1057/9781137039521

Mehl, Dieter. The Middle English Romances of the Thirteenth and Fourteenth Centuries. London: Routledge and Keegan Paul, 1968.

Morgan, Gerald. "Chaucer's Man of Law and the Argument for Providence." Review of English Studies 61, no. 248 (2010): 1-33. http://dx.doi.org/10.1093/res/hgp049

Nakley, Susan. "Sovereignty Matters: Anachronism, Chaucer's Britain, and England's Future Past." The Chaucer Review 44, no. 4 (2010): 368-96. http://dx.doi.org/10.5325/chaucerrev.44.4.0368

Nowlin, Steele. "The Legend of Good Women and the Affect of Invention." Exemplaria 25, no. 1 (2013): 16-35. http://dx.doi.org/10.1179/1041257312Z.00000000023

Pearsall, Derek. The Canterbury Tales. New York: Routledge, 1985.

Peter of Limoges. The Moral Treatise on the Eye. Translated by Richard Newhauser. Toronto: Pontifical Institute for Medieval Studies, 2012.

Robertson, Elizabeth. "The 'Elvyssh' Power of Constance: Christian Feminism in Geoffrey Chaucer's Man of Law's Tale." Studies in the Age of Chaucer 23 (2001): 143-80.

Robinson, Katelynn. "The Anchoress and the Heart's Nose: The Importance of Smell to Medieval Women Religious." Magistra 19, no. 2 (2013): 41-64.

Schibanoff, Susan. "Worlds Apart: Orientalism, Antifeminism, and Heresy in Chaucer's Man of Law's Tale." Exemplaria 8, no. 1 (1996): 59-96. http://dx.doi.org/10.1179/exm.1996.8.1.59

Shouse, Eric. "Feeling, Emotion, Affect." M/C Journal 8, no. 6 (2005). http://journal.media-culture.org.au/0512/03-shouse.php. 
Spearing, A.C. Textual Subjectivity: The Encoding of Subjectivity in Medieval Narratives and Lyrics. New York: Oxford University Press, 2005.

http://dx.doi.org/10.1093/acprof:oso/9780198187240.001.0001

Trigg, Stephanie, ed. "Premodern Emotions." Special issue, Exemplaria 26, no. 1 (2014).

Webb, Heather. The Medieval Heart. New Haven: Yale University Press, 2010.

http://dx.doi.org/10.12987/yale/9780300153934.001.0001 